\title{
EVALUASI PENERAPAN PEMERIKSAAN KESEHATAN TENAGA KERJA DI BALAI BESAR PENGEMBANGAN KESELAMATAN DAN KESEHATAN KERJA KOTA MAKASSAR
}

\section{EVALUATION OF MEDICAL CHECK-UP FOR LABOR IMPLEMENTED AT BALAI BESAR PENGEMBANGAN KESELAMATAN DAN KESEHATAN KERJA KOTA MAKASSAR}

\author{
Ridwan $^{1}$ dan Najmi Kamariah ${ }^{2}$ \\ ${ }^{1}$ Kantor Badan Kepegawaian dan Pelatihan Pendidikan Kota Jayapura \\ e-mail: ridwan@yahoo.com \\ ${ }^{2}$ Sekolah Tinggi Ilmu Administrasi-Lembaga Administrasi Negara Makassar \\ e-mail: najmikamariah@gmail.com
}

\begin{abstract}
Abstrak
Kegiatan Pemeriksaan kesehatan pada tenaga kerja masih menjadi kendala dalam penerapannya karna tidak dilakukanya pemeriksaan kesehatan awal dan kesehatan khusus pada tenaga kerja. Berdasarkan permasalahan tersebut maka penelitian ini bertujuan untuk Mengevaluasi Penerapan Pemeriksaan Kesehatan Tenaga Kerja di Balai Balai Besar Pengembangan Keselamatan dan Kesehatan kerja, Sesuai Permenakertrans No. 02 tahun 1980 tentang pemeriksaan kesehatan dan Penyeleggaraan keseselamatan kerja. Metode penelitian yang digunakan adalah pendekatan kualitatif yang menggambarkan serta mengamati secara mendalam tentang evaluasi penerapan pemeriksaan kesehatan tenaga kerja di Balai Besar Pengembangan Keselamatan Dan Kesehatan Kerja. Sumber data yang dianalisis adalah hasil wawancara, Pengamatan langsung pada Bidang Pelayanan, Bidang Umum Tenaga Kerja serta telaah dokumen di Balai Besar Pengembangan Keselamatan Dan Kesehatan Kerja makassar. Hasil Penelitian menunjukkan bahwa penerapan pemeriksaan kesehatan pada tenaga kerja pada perusahaan masih belum efektif karena belum diterapkan pemeriksaan kesehatan awal dan khusus, rekomendasi yang ditawarkan peneliti kepada BBPK3 untuk merevisi atau amandemen undang-undang no.1 tahun 1970 tentang keselamatan kerja dan penerapan ISO 15189 tentang akreditasi laboratorium klinik Agar perusahaan dapat menerapkan Pemeriksaan Kesehatan kerja Awal,berkala dan khusus, supaya Pemeriksaaan Kesehatan Tenaga Kerja semakin sempurna guna meningkatkan efisiensi dan pencapaian tingkat kinerja tenaga kerja lebih tinggi.
\end{abstract}

Kata Kunci: Pemeriksaan Kesehatan, Kesehatan dan Keselamatan Kerja

\section{Abstract}

Health inspection activities on the workforce is still a challenge in its application because no initial health checks and special health checks on the workforce. Based on these considerations, this study aims to evaluate the application of labor inspection in the Center for Occupational Safety and Health Development, in accordance with Minister of Manpower and Transmigration No. 02 of 1980 concerning health checks and work safety management. The research method used was qualitative 
discussion material that discussed health issues at the Center for Occupational Safety and Health Development. Data sources analyzed were the results of interviews, direct observations in the field of services, the general field of labor and document review at the Makassar Center for Occupational Safety and Health Development. Research results related to the implementation of medical examinations in companies are still ineffective because they apply initial and special health examinations, the discussion offered by researchers for BBPK3 to revise or amend, Law No. 1 of 1970 concerning work safety and the application of ISO 15189 on clinical laboratory accreditation so that companies can examine initial, periodic and special occupational health, examine the workforce health of workers to improve efficiency and improve workforce performance higher.

Keywords: Health Check, Occupational Health and Safety

PENDAHULUAN

Kondisi Keselamatan dan Kesehatan Kerja (K3) perusahaan di Indonesia secara umum diperkirakan termasuk rendah. Indonesia akan sulit menghadapi pasar global karena mengalami ketidak efisienan pemanfaatan tenaga kerja (produktivitas kerja yang rendah). Padahal kemajuan perusahaan sangat ditentukan peranan mutu tenaga kerjanya. Karena itu disamping perhatian perusahaan, pemerintah juga perlu memfasilitasi dengan peraturan perlindungan Keselamatan dan Kesehatan Kerja Suma'mur (1981).

Sumber daya manusia merupakan aset perusahaan yang sangat penting dalam kaitannya dalam produksi, dan untuk itu perlu di upayakan agar tingkat kesehatan tenaga kerja selalu dalam keadaan optimal. Interaksi tenaga dan risiko, untuk itu segala upaya harus dilakukan untuk mengurangi dampak negative tersebut, karena hanya pada kondisikerja yang sehat dan aman seorang pekerja dapat bekerja dengan aman, efektif dan efisien.
Berdasarkan peraturan menteri tenaga kerja dan transmigrasi no. 02/MEN/1980, pemeriksaan kesehatan merupakan agenda wajib yang harus dilakukan oleh pemilik perusahaan kepada pekerja. Hal ini dilakukan untuk menghindari adanya yang disebabkan oleh riwayat penyakit yang diderita oleh pekerja, ataupun gangguan-gangguan fisik dan mental yang tidak diketahui oleh pemilik perusahaan. Pemeriksaan kesehatan biasanya dilakukan pada saat sebelum kerja, dan pemeriksaan berkala yang dilakukan di saat-saat tertentu, serta pemeriksaan khusus yaitu pemeriksaan kesehatan dimana terjadi permasalahan yang timbul akibat beban kerja maupun lingkungan kerja.

Era globalisasi dan pasar bebas yang akan berlaku tahun 2020 mendatang, Keselamatan dan Kesehatan Kerja (K3) merupakan salah satu prasyarat yang ditetapkan dalam hubungan ekonomi perdagangan barang dan jasa antar negara yang harus dipenuhi oleh seluruh negara anggota. Masalah Keselamatan dan 
Kesehatan Kerja masih sering terabaikan. Hal ini ditunjukkan dengan masih tingginya angka kecelakaan kerja. Keselamatan dan Kesehatan Kerja amat berkaitandengan upaya pencegahan kecelakaan dan penyakit akibat kerja dan memiliki jangkauan berupa terciptanya masyarakat dan lingkungan kerja yang aman, sehat dan sejahtera, serta efisien dan produktif.

\begin{tabular}{llr} 
Balai Besar & \multicolumn{2}{r}{ Pengembangan } \\
Keselamatan dan & Kesehatan & Kerja \\
(BBPK3) mempunyai tugas pokok
\end{tabular}
melaksanakan pengembangan pengujian dan pemeriksaan Keselamatan dan KesehatanKerja, peningkatan kapasitas tenaga Keselamatan dan KesehatanKerja, serta pemberdayaan di bidang Keselamatan dan Kesehatan Kerja. Dalam melaksankan tugas sebagaimana di maksud dalam tugas pokok diatas, Balai Besar Pengembangan Keselamatan dan Kesehatan Kerja Makassar menyelenggarakan fungsi: Penyusunan rencana, program, dan anggaran; Pelaksanaan pengujian dan pemeriksaan Keselamatan dan Kesehatan Kerja; Pelakasanaan analisis, perekayasaan, penerapan teknologi dan uji coba Keselamatan dan Kesehatan Kerja; Pelaksanaan peningkatan kapasitas tenaga Keselamatan dan Kesehatan Kerja; Pelaksanaan pemberdayaan Keselamatan dan Kesehatan Kerja; Evaluasi dan penyusunan laporan; Pelaksanaan urusan tata usaha dan rumah tangga. (Arikunto, 2013).

Adapun posisi BBPK3 kesehatan kerja berada pada lingkup pekerja dan lebih menekankan pada aspek promosi terhadap kesehatan para pekerja sementara posisi keselamatan berada pada aspek interaksi yang ada dalam system kerjaatau proses kerja dan mempunyai peran Kesehatan dan Keselamatan dalam ilmu Kesehatan kerja berkontribusi dalam upaya perlindungan kesehatan para pekerja dengan upaya promosi kesehatan, pemantauan dan survailan kesehatan serta upaya peningkatan daya tubuh dan kebugaran pekerja.

Dari hasil pemantauan dan wawancara awal pada tanggal 12 Februari 2019 kepada Kepala BidangTeknis Balai Besar Pengembangan Keselamatan dan Kesehatan Kerja Makassar, terkait dengan pemeriksaan kesehatan awal atau sebelum bekerja terhadap tenaga kerja masih banyak perusahaan yang tidak melmiliki data base pemeriksaan kesehatan awal pada padatenaga kerja dan pemeriksaan kesehatan khusus.

Berdasarkan data tersebut maka peneliti ingin melihat dan mengkaji pelayanan pemeriksaan kesehatan pada pekerja kerja pada perusahaan yang dilakukan oleh Balai Besar Pengembangan Keselamatan dan Kesehatan Kerja Makassar serta kendala apa yang membuat 
perusahaan tidak menerapkan pemeriksaan kesehatan awal dan pemeriksaan secara khusus.

Adapun tujuan dari penelitian ini adalah untuk mengetahui sejauh mana Kegiatan dan pelayanan pemeriksaan kesehatan tenaga kerja di Balai Besar Pengembangan Keselamatan dan Kesehatan Kerja Makassar. Menunjukkan bahwa data yang ada di balai besar pengembangan $\mathrm{K} 3$ semua perusahaan tidak memiliki data terkait pemeriksaan kesehatan awal dan pemeriksaan kesehatan khusus Sementra pemeriksaan kesehatan sebelum bekerja dijabarkan dalam peraturan yang sama di dalam pasal 2 UU Nomor 1 tahun 1970 yang menjelaskan bahwa Pemeriksaan Kesehatan sebelum bekerja ditujukan agar tenaga kerja yang diterima berada dalam kondisi kesehatan yang setinggi-tingginya, tidak mempunyai penyakit menular yang akan mengenai tenaga kerjalain nya.

Dari hasil pemantauan dan wawancara awal pada tanggal 12 Februari 2019 kepada Kepala BidangTeknis Balai Besar Pengembangan Keselamatan dan Kesehatan Kerja Makassar, terkait dengan pemeriksaan kesehatan awal atau sebelum bekerja terhadap tenaga kerja masih banyak perusahaan yang tidak melmiliki data base pemeriksaan kesehatan awal pada padatenaga kerja dan pemeriksaan kesehatan khusus.
Berdasarkan data tersebut maka peneliti ingin melihat dan mengkaji pelayanan pemeriksaan kesehatan pada pekerja kerja pada perusahaan yang dilakukan oleh Balai Besar Pengembangan Keselamatan dan Kesehatan Kerja Makassar serta kendala apa yang membuat perusahaan tidak menerapkan pemeriksaan kesehatan awal dan pemeriksaan secara khusus.

\section{METODE PENELITIAN}

Desain peneitian yang digunakan dalam penelitian ini adalah penelitian kualitatif. Penelitian kualitatif adalah metode penelitian yang mengumpulkan dan menganalisis data berupa kata-kata (lisan maupun tulisan) dan perbuatan-perbuatan manusia. (Sugiyono, 2011) Penelitian ini akan dilakukan di Balai Besar Pengembangan keselamatan dan Kesehatan Kerja Makassar dan pengambilan data rencananya akan dilaksanakan pada bulan April sampai bulan Mei 2019.

Informan dalam penelitian ini adalah orang atau pelaku yang benar-benar tahu dan menguasai masalah, serta terlibat langsung dengan masalah penelitian. Pemilihan informan sebagai sumber data dalam penelitian ini adalah berdasarkan pada asas subyek yang menguasai permasalahan, memiliki data dan bersedia memberikan informasi lengkap dan akurat. Informan Kunci adalah Penanggung Jawab 
Pemeriksaan Kesehatan pada pekerja di Balai Besar Pengembangan Keselamatan dan Kesehatan Kerja termasuk Kepala Balai, Kepala Bidang Teknis, Dokter dan Petugas Kesehatan terkait pelayanan pemeriksaan kesehatan Kerja.

Informan Biasa adalah Tenaga kerja yang telah melakukan pemeriksaan kesehatan kerja di Balai Besar Pengembangan Keselamatan dan Kesehatan Kerja Makassar dan bersedia berperan serta dalam penelitian ini. Untuk pengumpulan data ini, maka peneliti akan menggunakan tekni-teknik analisis data.

\section{HASIL PENELITIAN}

\section{Pemeriksaan Kesehatan Awal}

Berdasarkan hasil wawancara dengan Kepala BBPK3 mengungkapkan bahwa kendala dalam penerapan pemeriksaan kesehatan kerja yaitu dimana tidak semua perusahaan melakukan pemeriksaan kesehatan kerja sehingga kembali pada pengawasan tenaga kerja yang menginstruksikan perusahaan melakukan pemeriksaan kesehatan kerja berdasarkan peraturan perundang-undangan.

Identitas nama, umur, jenis kelamin, alamat tertulis, status perkawinan, riwayat pekerjaan terdahulu, serta rencana penempatan dan jenis pekerjaannya. Anamnesis ditujukan untuk mendapatkan mendapatkan informasi sebanyakbanyaknya mengenai kemungkinan adanya penyakit yang diderita saat ini, riwayat penyakit terdahulu, riwayat penyakit keluarga serta riwayat adanya pemeparan faktor bahaya dilingkungan kerja sebelumnya.

Pemeriksaan fisik dilakukan secara menyeluruh dan sistimatik meliputi pemeriksaan keadaan umum, tanda fungsi vital, pemeriksaan ketajaman penglihatan, THT, pemeriksaan jantung, paru, perut dan organ gerak. Pemeriksaan penunjang meliputi pemeriksaan foto rontgen, laboratorium rutin serta pemeriksaan lain yang dianggap perlu. Pemeriksaan penunjang lainnya dapat bervariasi tergantung dari kebutuhan, Misalnya calon karyawan yang akan ditempatkan pada unit kerja dangan tingkat kebisingan tinggi, sebaiknya perlu perlu ditambahkan pemeriksaan audiometri.

Akan tetapi hal tersebut tidak sesuai dengan fakta yang ada dimana hampir semua perusahaan tidak melakukan pemeriksaan awal dalam melakukan penerimaan tenaga kerja. Hal ini juga di pengaruhi lemahnya pengawasan Ketenagakerjaan akhir berdampak pada Balai Besar Pengembangan Keselamatan dan Kesehatan Kerja dibawah naungan Binwasnaker selaku instansi terkait dalam pelayanan pemeriksaan kesehatan tenaga kerja di perusahaan.

Untuk mengetahui lebih jelasnya terkait pemeriksaan awal tersebut, peneliti 
melakukan wawancara mendalam (indepht Interview) kepada tenaga kerja yang ada di suatu perusahaan. Adapaun hasil wawancara yang dilakukan mengenai pernah tidaknya dilakukan pemeriksaan kesehatan awal sebelum masuk ke perusahaan, dimana informan (tenaga Kerja) menyampaikan hasil wawancara yang dilakukan terkait dengan pemeriksaan awal yaitu informan (tenaga Kerja) menyampaikan bahwa tidak pernah dilakukan pemeriksaan awal pada saat penerimaan tenaga kerja.

Selain itu hasil wawancara kepada informan terkait keterangan berbadan sehat yang menjadi persyaratan dari pihak perusahaan, dimana informan 1 yaitu tenaga kerja mengungkapkan hasil wawancara dengan Informan 1 yaitu tenaga kerja mengungkapkan bahwa dia diminta untuk melampirkan surat keterangan berbadan sehat dari dokter oleh perusahaan sebagai syarat melamar sebagai tenaga kerja di perusahaan tersebut.

Dari wawancara bersama Informan 2 yaitu tenaga kerja mengemukakan bahwa dia tidak pernah diminta untuk malampirkan surat keterangan berbadan sehat oleh pihak perusahaan. Sementara itu berdasarkan informasi dari hasil wawancara dengan beberapa informan dimana informan 3, 4, dan 5 sejalan dengan informasi yang di sampaikan oleh informan 1, yaitu harus melampirkan surat keterangan berbadan sehat dari dokter atau puskesmas sebagai persyaratan diterima menjadi tenaga kerja pada perusahaan.

Selanjutnya dalam proses penelitian ini, informan (tenaga kerja) juga dimintai keterangan terkait pengetahuan tenaga kerja mengenai Undang - Undang Nomor 1 tahun 1970 tentang keselamatan kerja dan Permenaker No. 02 Tahun 1980 tentang pemeriksaaan kesehatan dan penyelenggara keselamatan kerja. Adapun hasil wawancara kepada informan yaitu tenaga kerja adalah berdasarkan hasil wawancara dengan informan, rata - rata mengatakan bahwa mereka tidak tahu terkait aturan ataupun Undang -Undang yang menjadi landasan ketenaga kerjaan. Bebeapa informan juga mengungkapkan tahu dengan aturan tersebut akan tetapi masih diabaikan oleh perusahaan maupun pengawas karena sangsinya terlalu ringan.

Dalam penelitian ini bukan hanya tenaga kerja atau karyawan yang menjadi informan akan tetapi pihak BBPK3 juga merupakan informan yang sangat penting dimana selaku informan kunci untuk memperoleh informasi mengenai obyek penelitian. Berikut hasil wawancara terhadap informan kunci yaitu kepala BBPK3 mengungkapkan terkait pemeriksaan awal adalah Sejalan dengan apa yang diutarakan oleh kepala BBPK3, infoman 6 yaitu kepala bidang tekhnis 
BBPK3 juga mengungkapkan hal terkait pemeriksaan awal.

Berdasarkan informasi yang disampaikan dua informan kunci diatas yaitu perlu adanya pemeriksaan kesehatan kerja baik itu kesehatan awal, berkala dan khusus dimana hal tersebut diatur dalam Undang - Undang dan itu wajib dilaksanakan oleh semua perusahaan yang berada dalam wilayah Indonesia.

Informasi dari informan 8 yaitu petugas lapngan menegaskan bahwa tidak pernah ada pemeriksaan kesehatan awal yang dilakukan dalam rekruitmen tenaga kerja dala suatu perusahaan.

Dari hasil Wawancara dengan Informan 8 yaitu petugas lapangan mengungkapkan bahwa kendala yang di temukan dalam hal ini, petugas lapangan tidak bisa mendignsis atau menentukan penyakit akbat kerja karena tidak adanya data awal yang dimiliki oleh Balai Besar Pengebangan Keselamatan dan kesehatan Kerja terkait pemeriksaan awal tenaga kerja.

Informan 9 yang juga merupakan petugas lapangan juga mengungkapkan kendala dalam melakukan pemeriksaan kesehatan terhadap tenaga kerja, berdasarkan hasil wawancara yang dilakukan di temukan informasi sebagai berikut

Hal diatas juga searah dengan pemaparan informan 9 yang juga merupakan perugas kesehatan. Berdasarkan hasil wawancara dari beberapa informan diatas mengungkapkan bahwa begitu pentingnya dilakukan pemeriksaan kesehatan awal tenaga kerja, dimana nantinya akan menjadi acuan data awal untuk mendiagnosa atau menentukan penyakit akibat kerja dan juga menjadikan perusahaan taat aturan dimana akan tertibnya peraturan atau Undang - Undang Nomor 1 tahun 1970 tentang keselamatan kerja dan Permenaker 02 tahun 1980 tentang pemeriksaan ksehatan dan penyelenggaraan keselamatan kerja.

Pemeriksaan kesehatan awal atau sebelum bekerja merupakan hal yang sangat penting dilakukan dalam sebuah perusahaan agar tenaga keja yang akan diterima berada dalam kondisi kesehatan yang setinggi-tingginya. Tidak mempunyai penyakit menular yang akan mengenai tenaga kerja lainnya, dan cocok untuk pekerjaan yang dilakukannya sehingga keselamatan dan kesehatan kerja yang bersangkutan dan tenaga kerja lainnya juga dapat dijamin. Adapun tujuan dari pemeriksaan kesehatan awal adalah sebagai data medis dasar yang dapat dipakai sebagai pertimbangan untuk kepentingan pengajuan kompensasi dan mempermudah menyelasaikan masalah tentang penyakit akibat kerja Apabila dikemudian hari terjadi suatu penyakit/gangguan sebagai akibat dari pekerjaannya. Sehinggah 
perusahaan dapat memperhatikan hak tenaga kerja untuk mendapatkan jaminan kecelakaan kerja dan penyakit akibat kerja.

Setelah dilakukan pemeriksaan kesehatan Awal atau sebelum bekerja maka kesimpulan yang diambil dapat digolongkan menjadi bahwa calon tenaga kerja yang diterima yaitu dapat melakukan segala macam pekerjaan dan tidak ada kelainan fisik atau cacat selain itu tenaga kerja yang melakukan pekerjaan atau tugas tertentu yang terbatas karena adanya efek atau penyakit yang menetap. Tenega kerja ini dapat melakukan pekerjaan yang khusus dan ditempatkan pada tempat yang sesuai dengan kondisi kesehatannya serta tidak berbahaya pada dirinya maupun orang yang disekitarnya.

\section{Pemeriksaan Kesehatan Berkala}

Kesimpulan yang diambil dari pemeriksaan kesehatan berkala tenaga kerja yaitu Sehat, Perlu tindak lanjut untuk kelainan medis yang ditemukan.

Pada penelitian yang dilakukan, peneliti mencoba mengumpulkan informasi dengan menggunakan metode wawancara kepada informan terkait pemeriksaan kesehatan berkala tersebut. Adapun hasil wawancara dengan beberapa informan terkait.

Berdasarkan hasil wawancara dengan informan diatas yaitu dengan tenaga kerja, mengemukakan bahwa pernah dilakukan pemeriksaan kesehatan berkala akan tetapi dilakukan hanya 1 kali dalam setahun. Sementara itu pemeriksaan berkala sangat penting, karna dimana kita bisa mengetahui kondisi kesehatan tenaga kerja sehinga perusahaan dapat mempertahankan derajat kesehatan tenaga kerjanya.

Penerapan pemeriksaan kesehatan berkala sangat penting dilakukan dalam suatu perusahaan untuk menjanjamin kesehatan tenaga kerja dalam beraktivitas atau menjalankan pekerjaannya. Adapun hasil wawancara yang dilkukan bersama informan 5 yaitu tenaga kerja.

Sejalan dengan informasi yang dipaparkan oleh informan 1 , informan 5 yang juga merupakan tenaga kerja pada suatu perusahaan mengatakan bahwa informan 5 mengungkapkan bahwa pemeriksaan berkala itu sangat penting untuk tenaga kerja, dimana tenaga kerja sangat membutuhkan dan berharap adanya upaya yang dilakukan oleh balai k3 untuk merekomendasikan perusahaan melakukan pemerikasaan juga sebagai kontrol tenaga kerja mengenai dampak penyakitnya.

\section{Pemeriksaan Kesehatan Khusus}

Berdsarkan hasil wawancara yang dilakukan bersama beberapa informan di temukan informasi bahwa tidak ada dan tidak pernah dilakukan pemeriksaan khusus terhadap tenaga kerja perusahaan dan informan juga tidak tahu seperti apa itu 
pemeriksaan kesehatan khusus, sementara informan juga mengemukakan bahwa apabila tenaga kerja mengalami sakit akibat kerja disuruh atau di perintahkan memeriksakan kesehatannya di puskesmas atau dirumah sakit saja.

Selain dari proses penelitian yang dilakukan oleh peneliti terkait variabel diatas, peneliti juga melakukan wawancara mendalam kepada Kepala BBPK3, Kepala Bidang Tehknis BBPK3, dan Petugas Lapangan BBPK3 sebagai Informan Kunci mengenai pemeriksan kesehatan Kerja pada tenaga kerja suatu perusahaan.

Adapun informasi yang di temukan pada saat melakukan wawancara bersama informan yaitu kepala Balai BBPK3 terkait kendala dalam penerapan pemeriksaan kesehatan tenaga kerja baik itu awal, bekala, mapun khusus.

Berdasarkan hasil wawancara dengan Kepala BBPK3 mengungkapkan bahwa kendala dalam penerapan pemeriksaan kesehatan kerja yaitu dimana tidak semua perusahaan melakukan pemeriksaan kesehatan kerja sehingga kembali pada pengawasan tenaga kerja yang menginstruksikan perusahaan melakukan pemeriksaan kesehatan kerja berdasarkan peraturan perundang-undangan. Sementara informan lainnya yaitu kepala bidang tehknis BBPK3 juga memberikan informasi terkait kendala pelaksanaan pemeriksaan kesehatan kerja.
Dari hasil wawancara bersama Informan 7 hampir sama dengan ungkapan kepala balai BBPK3, Kepala bidang tehknis Juga mengungkapkan bahwa belum semua perusahaan mengerti dan paham tentang Keselamatan dan kesehatan kerja, sehingga belum semua perusahaan sadar akan pentingnya pemeriksaan kesehatan awal, berkala, maupun khusus disamping Klinik medis Balai Besar Pengembagan Keselamatan Dan Kesehatan Kerja belum ISO atau akreditasi.

Selain itu petugas lapangan yang juga sebagai informan dalam penelitian ini mengungkapkan terkait kendala dalam penerapan pemeriksaan kesehatan terhadap tenaga kerja dalam suatu perusahaan adalah dari hasil Wawancara dengan Informan 8 yaitu petugas lapangan mengungkapkan bahwa kendala yang di temukan dalam hal ini, petugas lapangan tidak bisa mendignsis atau menentukan penyakit akbat kerja karena tidak adanya data awal yang dimiliki oleh Balai Besar Pengebangan Keselamatan dan kesehatan Kerja terkait pemeriksaan awal tenaga kerja.

Informan 9 yang juga merupakan petugas lapangan juga mengungkapkan kendala dalam melakukan pemeriksaan kesehatan terhadap tenaga kerja, berdasarkan hasil wawancara yang dilakukan bersama informan 9 yang menungkapkan bahwa perlu adanya pembenahan klinik BBPK3 terutama 
masalah administrasinya dimana seharusnya semua data base hasil pemeriksaan kesehatan tenaga kerja sudah bisa tersimpan rapih sehingga apabilah ada masalah penyakit akibat kerja, BBPK3 dapat melakukan tindakan yang cepat melihat dari data awal yang dimiliki.

Selain dari kendala yang dihadapi peneliti juga menggaili informsi mengenai alternative solusi terkait pelaksanaan pemeriksaan kesehatan kerja. Dalam hal ini yang menjadi informan adalah Kepala BBPK3 dimana hasil wawancara yang didapatkan Kepala BBPK3 mengungkapkan bahwa seharusnya petugas dalam hal ini pengawas Ketenagakerjaan yang punya kewenangan supaya semua perusahaan dapat melakukan pemeriksaan kesehatan kerja awal, berkala, dan khusus supaya mejadi acuan kontrol tenaga kerja melalui data base, apakah tenega kerja mengalamii penyakit akibat kerja atau penyakit bawaan.

Sementara itu informan 7 yaitu kepala bidang tehknis menyampaikan informasi terkait alternatif solusi terkait pemeriksaan kesehatan di perusahaan. Kepala bidang tehknis mengungkapkan bahwa seharusnya ada pemegang kuasa terkait kewenangan memastikan pemeriksaan terkait dibelakukannya Undang - Undang Nomor 1 Tahun 1970, dan kontrol yang tegas terhadap pihak perusaahaan untuk melakukan pemeriksaan kesehatan tersebut.

Selain dari inform diatas informan lain yaitu petugas lapangan juga memberikan saran terkait penerpan pemeriksaan kesehatan terhadap tenaga kerja tersebut. Adapun hasil wawancara yang dilakukan adalah Petugas lapangan selaku informan 8 mengungkapkan bahwa setiap perusahaan wajib melakukan pemeriksaan kesehatan tenaga kerja baik itu awal, berkala maupun khusus agar muda petugas muda mendeteksi penyakit akibat kerja dan penyakit tertentu yang dialami olah tenaga kerja.

Sejalan dengan informan 8 , informan 9 yang juga selaku petugas lapangan mengemukakan bahwa Informan 9 mengemukakan bahwa, sebagai saran kedepan pegawai pengawas dapat merekomendasikan perusahaan untuk melakukan pemeriksaan kesehatan awal terhadap tenaga kerjanya sebagai upaya mengadakan hasil diagnosis penyakit akibat kerja.

Berdasarkan hasil wawancara diatas ditemukan solusi dan saran yaitu perlunya ketegasan oleh pengawas terhadap perusahaan untuk melakukan dan memaksimalkan pemeriksaan kesehatan kerja awal, berkala, dan khusus terhadap tenaga kerja sehingga diperoleh data hasil diagnosis penyakit akibat kerja dan itu 
dianggap sebagai suatu yang seharusnya diimplementasikan oleh perusahaan.

\section{PEMBAHASAN}

Berdasarkan Peraturan menteri tenaga kerja dan Transmigrasi No. 02 /MEN/ 1980 tentang Pemeriksaan Kesehatan merupakan agenda wajib yang harus dilakukan oleh pemilik perusahaan kepada pekerja. Hal ini dilakukan untuk menghindari adanya kecelakaan kerja yang disebabkan oleh riwayat penyakit yang diderita oleh tenaga kerja. ataupun gangguan-gangguan fisik dan mental yang tidak diketahui oleh pemilik perusahaan. Pemeriksaan kesehatan kerja bisanya dilakukan disaat sebelum bekerja, Adapun tujuan dari pemeriksaan kesehatan Kerja Awal (sebelum bekerja) adalah ditujukan agar tenaga kerja yang diterima berada dalam kondisi kesehatan yang setinggi-tingginya, tidak mempunyat menular yang akan mengenai tenaga kerja lainnya dan cocok untuk pekerjaan yang akan dilakukan sehingga keselamatan dan kesehatan tenaga kerja yang bersangkutan dan tenaga kerja lainya dapat terjamin. Berdasarkan hasil wawancara yang dilakukan terhadap informan, menyampaikan bahwa tidak dilakukan pemeriksaan kesehatan awal atau sebelum bekerja dan informan dengan nota bene selaku tenaga kerja hanya membawa surat keterangan berbadan sehat sebagai kelengkapan berkas permohonan diterimanya bekerja diperusahaan tersebut, namun yang terjadi pada tenaga kerja diperusahaan berbanding terbalik dengan apa yang seharusnya menjadi pedoman peraturan Undang-undang Republik Indonesia Nomor 1 tahun 1970 tentang keselamatan kerja yaitu pada pasal 2 ayat (2) yang menyebutkan bahwa harus mengadakan pemeriksaan kesehatan sebelum bekerja sedangkan Pasal 8 ayat (1) bahwa Pengurus diwajibkan memeriksakan kesehatan badan, kondisi mental dan kemampuan fisik dari tenaga kerja yang akan diterimahnya maupun akan dipindahkan sesuai dengan sifat-sifat pekerjaan yang diberikan kepadanya, dan di pertegas juga dalam peraturan menteri tenaga kerja dan transmigrasi No. Per. 02 tahun 1980 tentang pemeriksaan kesehatan tenaga kerja dan penyelenggaraan keselamatan kerja yaitu pada pasal (2 )ayat (1) yang menyebutkan bahwa pemeriksaan sebelum bekerja ditujukan agar tenaga kerja yang diterima berada dalam kondisi kesehatan yang setinggi-tingginya, tidak mempunyai penyakit menular yang akan mengenai tenaga kerja lainnya, dan cocok untuk pekerjaan yang akan dilakukan sehingga keselamatan dan kesehatan kerja yang bersangkutan dan tenaga kerja lainnya dapat dijamin. sementara tidak ada sangsi yang diberikan pada perusahaan maka dari itu untuk memberlakukan pemeriksaan kesehatan awal tenaga kerja tersebut 
diperlukan penguatan undang-undang No. 1 tahun 1970 tentang keselamatan kerja dengan cara melakukan perbaikan atau amandemen dan meningkatkan atau memberikan sangsi pada pihak perusahaan yang tidak memberlakukan undang-undang tersbut.

Salah satu tujuan dari pemeriksaan kesehatan berkala pada tenaga kerja adalah upaya pencegahan terhadap penyakit dan penunjang dalam menjaga kesehatan tenaga kerja dimana untuk deteksi dini penyakit sehingga dapat diatasi dengan lebih cepat, tepat dan efisien. Dengan upaya ini juga bisa menjadi masukan untuk perusahaan apakah penempatan tenaga kerja sudah sesuai dengan kondisi fisik pekerja. Pemeriksaan kesehatan berkala (Periodik) untuk tenaga kerja diperusahaan adalah sebagai dasar dan pembanding masa sekarang dengan masa sebelum bekerja dalam mendeteksi penyakit akibat kerja dan sebagai data untuk pengembangan kegiatan pencegahan dan promosi kesehatan kerja.

Pemeriksaan kesehatan berkala adalah pemeriksaan kesehatan pada waktu - waktu tertentu dalam artian bahwa pemeriksaan yang dilakukan 1 kali dalam setahun terhadap tenaga kerja yang dilakukan oleh dokter dan petugas kesehatan. Pemeriksaan kesehtan berkala ini juga diatur dalam Undang - Undang Nomor 1 Tahun 1970 tentang keselamatan kerja dan Permenaker 02 tahun 1980 tentang pemeriksaan kesehatan. Dalam ketentuannya, pemeriksaan kesehatan berkala ini harus dilakukan sekurangkurangnya satu tahun sekali. Adapun Pemeriksaan Kesehatan berkala meliputi pemeriksaan fisik lengkap, kesegaran jasmani, foto rontgen paru, laboratorium rutin serta pemeriksaan lain yang dianggap perlu, dalam hal ditemukan kelainan atau gangguan kesehatan pada pemeriksaan berkala. Perusahaan wajib mengadakan tindak lanjut untuk memperbaiki kelainan tersebut seperti (terapi, tindakan medis tertentu rujukan spesialis serta rehabilitasi dan mengatasi penyebabnya antara lain yaitu pengendalian lingkungan kerja untuk menjamin terselenggaranya Keselamatan dan Kesehatan Kerja.

Hasil penelitian bahwa sebagian perusahan sudah melakukan pemeriksaan kesehatan berkala terhadap tenaga kerja dimana diatur dalam Undang-Undang no. 1 tahun 1970 tentang keselamatan kerja dan Permenakertrans no. 02 tahun 1980 tentang pemeriksaan kesehatan kerja dan penyelenggara keselamatan kerja dimana BBPK3 sudah bisa mendapatkan data penyakit yang dialami oleh tenga kerja tersebut untuk direkomendasikan kepada tenaga kerja untuk berobat tetapi untuk menentukan Penyakit Akibat Kerja, Dokter dan Petugas Kesehatan sulit atau tidak bisa mendiagnosis Penyakit Akibat Kerja dimana kendalanya adalah tidak adanya 
Data Base Pemeriksaan kesehatan Awal tenaga kerja. Dimana diatur dalam Peraturan Menteri Tenaga Kerja Dan Transmigrasi No. Per. 01 tahun 1981 tentang Kewajiban Melapor Penyakit Akibat Kerja yaitu pasal 1 poin (a) yang menyebutkan bahwa Penyakit Akibat Kerja adalah Setiap penyakit yang disebabkan oleh pekerjaan atau lingkungan kerja.

Salah satu tujuan untuk pemeriksaan kesehatan khusus juga diatur dalam Peraturan Menteri tenaga kerja dan Transmigrasi No 02 tahun 1980 tentang pemeriksaan kesehatan tenaga kerja dalam penyelenggaraan keselamatan kerja. yang dimuat pada pasal 5 ayat (3) yang menyebutkan bahwa Pemeriksaan kesehatan Khusus diadakan pula terdapat keluhan-keluhan diantara tenaga kerja, atau atas pengamatan pegawai pengawas $\mathrm{K} 3$ atau atas penilaian Pusat Bina Hyperkes dan keselamatan dan Balai-balainya atau atas pendapat umum masyarakat.

Pemeriksaan kesehatan khusus adalah pemeriksaan kesehatan yang dilakukan oleh dokter secara khusus terhadap tenaga kerja tertentu. Pemeriksaan kesehatan yang dimaksudkan adalah untuk menilai adanya pengaruh - pengaruh dari pekerjaan tertentu terhadap tenaga kerja atau golongan tenaga kerja tertentu. Adapun contoh tentang pemeriksaan khusus antara lain tenaga kerja yang bekerja dengan resiko tertentu, misalnya pekerja yang berisiko terkena radiasi, menangani bahan kimia yang berbahaya. Tenaga kerja dibagian penyedia makanan, makanan, perlu dilakukan pemeriksaan terhadap tertentu, misalnya carrier penyakit tipus. Tenaga kerja yang karena fisik, mental serta penyakit yang dideritanya perlu istirahat, sakit secara terus menerus dalam waktu yang lama.

Pemeriksaaan kesehatan khusus merupakan hal yang sangat penting terhadap tenaga kerja untuk menilai adanya pengaruh dari pekejaan tertentu terhadap golongan tenaga kerja tertentu karna pemeriksaan kesehatan khusus dilakukan pada tenaga kerja yang telah mengalami kecelakaan atau penyakit yang memerlukan perawatan lebih dari dua minggu dan tenaga kerja yang diduga menderita gangguan kesehatan tertentu supaya mendapatkan jaminan pelayanan kesehatan kerja dari perusahaan yang sesuai dengan peraturan agar tenaga kerja dapat bekerja dengan sehat dan selamat dalam menunjang produktivitas tenaga kerja perusahaan.

Dalam pemeriksaan kesehatan khusus perlu Evaluasi dilakukan setelah satu tahun untuk menentukan apakah tenaga kerja tersebut telah mencapai maximum medical cure yang berarti telah mendapat pengobatan / tindakan medis yang maksimal yang bila dilanjutkan tidak ada perbaikan lagi. Dalam hal ini dapat dipertimbangkan pemutusan hubungan 
kerja dengan prosedur tertentu sesuai peraturan perundangan yang ada. Berdasarkan hasil penelitian yang dilakukan, ditemukan informasi dari wawancara dengan beberapa Informan diantaranya adalah tidak pernah ada pemeriksaan pemeriksaan khusus oleh peerusahaan atau dalam hal ini tenaga kerja yang dilakukan oleh BBPK3, Setiap tahunnya, dimana diatur dalam peraturan menteri tenaga kerja dan transmigrasi No. Per. 02 tahun 1980 tentang pemeriksaan kesehatan tenaga kerja dan penyenggaraan keselamatan kerja yaitu dimuat pada pasal (5) ayat (1) yang menyebutkan bahwa Pemeriksaan Kesehatan Khusus dimaksudkan untuk menilai adanya pengaruh-pengaruh dari pekerjaan tertentu terhadap tenga kerja atau golongangolongan tenaga kerja tertentu. Sedangkan ayat (3) yang menyebutkan bahwa Pemeriksaan Kesehatan Khusus diadakan pula apabila terdapat keluhan-keluhan diantara tenaga kerja, atau atas pengamatan Pegawai Pengawas keselamatan dan Kesehatan Kerja, atau atas penilaian Pusat Bina Hyperkes dan Keselamatan dan Balaibalainya yang Nota bene (BBPK3 Makassar) atau atas pendapat umum dimasyarakat. Padahal Fakta yang terjadi terhadap tenaga kerja diperusahaan berdasarkan hasil penelitian melalui wawancara pada Informan tidak pernah ada pemeriksaan kesehatan khusus dimana diamanatkan sesuai Peraturan Perundangundangan dan Permenakertrans RI. Menurut salah satu Informan yang sempat peneliti wawancarai dengan inisial (MJ) umur 37 tahun selaku Petugas Ahli K3 diperusahaan tersebut mengatakan bahwa apa bila terjadi kecelakaan kerja atau Penyakit yang dialami oleh tenaga kerja mungkin disebabkan oleh lingkungan kerja di perusahaan itu penderita hanya diberikan Rekomendasi untuk langsung berobat kepuskesmas atau rumah sakit yang menjadi rujukan perusahaan yang telah memberlakukan kerja sama BBPJS ketenagakerjaan. Berdasarkan penelitian yang dilakukan oleh peneliti, dalam rangka penerapan pelayanan pemeriksaan kesehatan tenaga kerja untuk meningkatkan derajat kesehatan yang setinggi-tingginya dalam hal ini tenaga kerja yang ada dalam perusahaan dibawah naungan BINWASNAKER, Bina K3 dan Balai Besar Pengembangan Keselamatan dan Kesehatan Kerja maka dengan ini peneliti berharap adanya dorongan/dukungan terbaik dari stake holder terkait pemeriksaan kesehatan kerja, dengan adanya peraturan perundangundangan No 1 tahun 1970, peneliti menganggap sangat lemah untuk menjamin secara tegas kesehatan dan keselamatan para pekerja. Undang-undang ini beserta peraturan dan pelaksanaannya sudah tidak sesuai dengan dinamika hari ini dan harus 
segera direvisi, maka dari itu untuk memaksimalkan pelayanan pemeriksaan kesehatan kerja (Awal, Berkala dan Khusus) untuk tenaga kerja tersebut diperlukan ada penguatan undang-undang No. 1 tahun 1970 tentang keselamatan kerja dan permenakerstran No. Per. 02 tahun 1980 tentang pemeriksaan kesehatan kerja dan penyelenggaraan keselamatan kerja. dengan cara melakukan perbaikan untuk itu Peneliti merasa perlu mendorong BBPK3 mengajukan usulan Binwasnaker dilakukannya revisi atau amandemen Undang-undang no. 1 tahun 1970 tentang Keselamatan Kerja guna mendukung terpenuhinya jaminanan Kesehatan Tenaga Kerja untuk meningkatkan derajat kesehatan yang setinggi-tingginya.dan tercapainya produktivitas tenaga kerja secara Nasional.

\section{KESIMPULAN DAN SARAN}

Berdasarkan hasil penelitian kualitatif dengan teknik wawancara mendalam (indepth interview) dan dokumentasi yang dilaksanakan di Balai Besar Pengembangan Keselamatan dan Kesehatan Kerja maka penulis dapat menarik kesimpulan bahwa Pemeriksaan kesehatan awal begitu penting dilakukan dimana hal ini akan menjadi acuan atau data awal tenaga kerja sehingga mudah mendiagnosis penyakit akibat kerja nantinya. wawancara yang dilakukan terkait dengan pemeriksaan awal pada informan biasa menyampaikan bahwa tidak pernah dilakukan pemeriksaan kesehatan awal pada saat penerimaan/rekrutmen tenaga kerja.

Kemudian informan kunci jmenyampaikan bahwa pemeriksaan kesehatan awal pada tenaga kerja tidak pernah dilakukan pemeriksaan awal pada perusahaan. Berdasarkan hasil wawancara dilakukan terhadap Informan menyampaikan bahwa sebagian perusahan sudah melakukan pemeriksaan kesehatan berkala terhadap tenaga kerja dimana diatur dalam undang-undang no. 1 tahun 1970 tentang keselamatan kerja dan permenakertrans no. 02 tahun 1980 tentang pemeriksaan kesehatan kerja dan penyelenggara keselamatan kerja dimana BBPK3 sudah bisa mendapatkan data penyakit yang dialami oleh tenga kerja tersebut untuk direkomendasikan kepada tenaga kerja untuk berobat tetapi untuk menentukan Penyakit Akibat Kerja, Dokter dan Petugas Kesehatan sulit atau tidak bisa mendiagnosis Penyakit Akibat Kerja. Hasil wawancara yang dilakukan bersama beberapa informan di temukan informasi bahwa tidak ada dan tidak pernah dilakukan pemeriksaan khusus terhadap tenaga kerja perusahaan dan informan juga tidak tahu seperti apa itu pemeriksaan kesehatan khusus, sementara informan juga mengemukakan bahwa apabila tenaga kerja 
mengalami sakit disuruh atau di perintahkan memeriksakan kesehatannya di puskesmas saja.

Berdasarkan hasil penelitian yang telah dilakukan oleh peneliti maka peneliti memberikan rekomendasi dengan Amandemen undang- undang No. 1 Tahun 1970 tetang keselamatan kerja. bahwa Undang-undang tersebut sudah tidak sesuai lagi dengan perkembangan, tuntutan, dan kebutuhan hukum dalam masyarakat atau tenaga kerja, apabila pihak Perusahaan yang tidak mentaati ketentuan-ketentuan dalam peraturan ini diancam dengan hukuman sesuai dengan Pasal 15 ayat (2) yaitu dapat memberikan ancaman pidana atas pelanggaran peraturannya dengan hukuman kurungan selama-lamanya 3 (tiga) bulan atau denda setingginya $\mathrm{Rp}$. 100.000,- (seratus ribu rupiah) sedangkan pada ayat (3) Tindak pidana tersebut adalah pelanggaran. sehingga perlu dicabut dan diganti dengan Undang-undang K3 yang baru. Agar Penerpan Pemeriksaan Kesehatan Tenaga kerja di Perusahaan Semakin Sempurna dan mencapai pada golongan Industry Zero Accident guna meningkatkan produksi dan produktifitas
Nasional. Penerapan Pelayanan Kesehatan dengan standar Akreditasi laboratorium medik ISO 15189:2012 yaitu merupakan standar yang berisi persyaratan bagi laboratorium medic untuk membuktikan kompetensinya dalam memberikan pelayanan yang akurat dan dapat dipertanggungjawabkan. Perlu memiliki system pemantauan data base tentang pemeriksaan kesehatan awal, berkala dan khusus pada perusahaan yang telah dilayani.

\section{DAFTAR PUSTAKA}

Arikunto, Suharsimi. Cepi, Safruddin AJ. 2010. Evaluasi Program Pendidikan. Jakarta: Bumi Aksara

Arikunto, Suharsimi. 2013. Prosedur Penelitian: Suatu Pendekatan Praktik. Jakarta: Rineka Cipata.

Gunawan, 2014 Metode Penelitian Pendidikan. Bandung: Alfabeta

Sugiyono. 2011. Metode Penelitian Kuantitatif, Kualitatif, Peneltian dan Pengembangan, Bandung: Alfabeta

Suma'mur, P.K. 1989. Keselamatan Kerja dan Pencegahan Kecelakaan. Jakarta: PT. Gunung Agung

Undang-Undang No.13 Tahun 2003 tentang ketenagakerjaan.

Undang-Undang Republik Indonesia Nomor 36 Tahun 2009 Tentang Kesehatan Pasal 53 UU Kesehatan.

Undang-Undang Nomor 25 Tahun 2009 Tentang Pelayanan Publik. 